\title{
The Historic (Wrong) Turn in Management and Organizational Studies
}

\section{Introduction}

History has long been a contested domain. In the nineteenth and early twentieth centuries the very purpose of history was challenged by idealist philosopher-historians such as Thomas Carlyle, Friedrich Nietzsche and Benedetto Croce. In his On the Use and Abuse of History for Life, Nietzsche (1874, pp. 25-26), for example, declared that "history" only serves useful purpose when it abandons its emphasis on factual veracity so as inspire action in "the present", turning itself into "a purely artistic picture". In a similar vein, Croce (1915/ 1921, pp. 73, 91) - who acted as inspiration for the late Hayden White - advised his readers that, "facts do not exist" and that, "The past does not live otherwise in the present". Until the 1970s, however, such idealist critiques were confined to the margins. Instead, most historians shared the view that societies were shaped by lived experience, and that it was the job of the historian to understand those experiences. As the Marxist historian, E.P. Thompson (1978, p. iii), expressed it, "Experience walks in without knocking at the door, and announces deaths, crises of subsistence, trench warfare ... In the face of such general experiences old conceptual systems may crumble and new problematics insist upon their presence." Admittedly, there was much disputation as to how past experiences can be ascertained and interpreted. On one extreme stood "positivists" such as G.R. Elton who held to the "skeptical empiricism" of David Hume (1748 / 1902, p. 36), a philosopher-historian who argued that, "From causes which appear similar we expect similar effects. This is the sum of all our experimental conclusions." At the other end of the spectrum were those who believed that social structures and economics constrained human choices, a circumstance that allowed the historian to postulate historical laws with some certainty, Karl Marx (1852 / 1951: 225) famously declaring,

Men make their own history, but ... they do not make it under circumstances chosen by themselves, but under circumstances directly encountered, given and transmitted from the past.

In all probability most twentieth-century historians stood between these two poles, choosing a science-based model of inquiry built around the testing of hypotheses, the French historian, Marc Bloch (1944 / 1951, p. 65) recording how "passive observation, even supposing such a thing were possible, has never contributed anything productive to any science." 
Today, the intellectual traditions that once occupied central place in historical research are threatened by various postmodernist theories, rooted in philosophic idealism. In the field of management and organizational studies - including the sub-discipline of management history an increasing number declare themselves proponents of the so-called "historic turn" initiated in 2004 by Peter Clark and Michael Rowlinson (2004, p. 331), who linked their "historic turn" to the "wider transformation that is alluded to in terms such as the 'discursive turn', deconstruction and post-modernism." Since then the "historic turn" has received wide endorsement. Thus, we are advised in the Routledge Companion of Management and Organizational History that all the editors - and, indeed, all the authors - "are collectively embedded within the varied interests and efforts comprising the historic turn" (Weatherbee, McLaren and Mills, 2015, p. 3). Similarly, Van Lent and Durepos (2019, pp. 429, 431), in a guest editorial for this journal, linked the "historic turn" to methodologies that reject "science paradigms in organization studies". The "historic turn" is also associated with a number of "critical management" sub-currents, namely ANTi-History (Durepos and Mills, 2011; Durepos and Mills, 2012; Durepos, 2015), history as rhetoric (Suddaby and Greenwood, 2005; Foster et al., 2017), "polyphonic constitutive historicism" (Smith and Russell, 2016) and "genealogical pragmatic analysis" (Marshall and Novicevic, 2016).

With the partial exception of Marshall and Novicevic's (2016, p. 104) "genealogical pragmatic analysis" - which posits a "genealogy" that meets "the standard methodological criteria of reliability, validity and verification" - all theories associated with the "historic turn" share a number of characteristics. First, history is seen not as a more-or-less accurate account of the past but rather as the historian's subjective creation. Arguing "that there is a 'literary' or 'fictive' element" in historical writing (Rowlinson, Hassard and Decker, 2014, p. 157), few proponents of the "historic turn" would likely object to Durepos, Shaffner and Taylor's $(2019$, p. 6) assessment that history "is always history for the ideological sake of someone or something". Second, proponents of the "historic turn" premise the superiority of their own ideas by contrasting them to a mythical "positivist", a strawman who little resembles any practicing historian. Instead, "positivist" history is rendered synonymous with von Ranke's (1821 / 1973, p. 5) observation that, "The historian's task is to present what actually happened". In attempting to convey "the past as it happened", Durepos and Mills (2011, p. 716 ) advise us, the "positivist" produces "hegemonic" histories that "instil a version of a history that is favourable to a dominant group". A third characteristic of the "historic turn" literature is that it follows in the footsteps of Nietzsche and Croce in associating "history" with an activist agenda, Durepos, Shaffner and Taylor (2019, p. 6), declaring that, "Our point is that doing historical research is an impactful vehicle to enact a leftist ideology". A fourth defining feature of the "historic turn" is found in the belief that the social scientist 
actually creates the world we inhabit. As McLaren and Durepos (2019, p. 5, 7) conclude, "Social reality is constructed through our efforts to define it."

Hailed as a pathway to "more heterogeneous forms of history" (Durepos, Shaffner and Taylor, 2019, p. 1,) in truth the "historic turn" represents a tragic wrong turn. For in examining the "historic turn" what one sees is a litany of misrepresentation, confusion and an unwillingness to even acknowledge well-known criticisms of their core understandings. Misrepresentation is most apparent in the ways "positivist" research is characterized, a descriptor that - with unconvincing exceptions sometimes made for "Marxists" (see, for example, Durepos and Mills, 2020, p. 66) - is used generically as if it applies to anyone who does not share the views of those associated with the historic (wrong) turn. As noted previously, there is a particular fondness for associating "positivism" with Ranke's observation that, "The historian's task is to present what actually happened". Such inferences not only overlook the diversity of "traditional" methodologies, they even misrepresent Ranke. For in making the observation that the historian should record "what actually happened" in an 1821 lecture, Ranke immediately qualified his statement, observing:

An event, however, is only partially visible to the world of the senses: the rest has to be added by intuition, inference, and guesswork ... the facts of history are in their several connecting circumstances little more than the results of tradition ... what actually happened ... is the necessary basis of history, its raw material, but not history itself.

The misrepresentation of all "non-postmodernist" historians as crude "positivists" points to what I argue are mistaken understandings of evidence, "facts" and "history". In essence, proponents of the historic (wrong) turn perceive social relationships emerging from the ways in which the world is depicted by researchers, rather than it being the case that the social relations emerge from a lived experience that the historian tries to capture. Thus, in believing that all history is no more than a social construct, exponents of the historic (wrong) turn confuse "facts" (i.e. things and experiences with a lived reality) and "evidence" (i.e. our always partial understanding of those facts) with the veracity of the resultant interpretation. Confused thinking on this score is apparent even in the ANTi-History framework devised by Durepos and Mills, a work which I (Bowden, 2018, p. 231) describe elsewhere as "the most significant attempt to address the internal failings of postmodernist thought." The fundamental premises (and flaws) of ANTi-History are, however, observable when we explore the quote with which Durepos and Mills (2011) began their first major account of their theory. For in drawing upon Latour and Woolgar's (1979 / 1986, p. 107) proposition that, "We do not attempt to ... determine 'what really happened' ... Instead 
our concern is to demonstrate how a hard fact can be sociologically constructed", Durepos and Mills (2011, pp. 703-704) are explicitly basing their own theoretical premises upon Latour's ActorNetwork Theory (ANT) and the study of scientific research upon which it was founded. In outlining their core argument in Laboratory Life, Latour and Woolgar (1979 /1986, p. 235) have us believe "that scientific activity comprises the construction and substance of fictional accounts" via actornetworks so that they come to be understood as accepted "fact". Subsequently, in a paper on Einstein's theory of relativity, Latour (1988, p. 14), reiterated this argument with the observation that, "texts" - including scientific theories - "are always, in the end, points of view, opinions, interpretations - that is to say, fictions." In other words, actor-networks are not a factor in the success of a theory. They are the only factor. Accordingly, as the physicist Alan Sokal (1997 / 2000 , p. 129) observed in repudiating Latour, ANT frameworks would have us conclude that one can "explain the history of the science [being considered] without taking into account the truth or falsity of the scientific theories in question."

Despite the fact that Sokal's attacks on Latour and like-minded thinkers becoming a cause célébre due to the so-called "Sokal Hoax" - associated with the publication of a parody of their work - nowhere in any of their discussions do ANTi-History proponents (Durepos and Mills, 2011, 2012; Durepos, 2015; Shaffner, Mills and Mills, 2019) ever acknowledge Sokal's criticisms. Nor, indeed, do they advise the reader of any significant criticisms of ANT, or their defence against such attacks. Such unfortunate habits have characterized the historic (wrong) turn since its inception. If we turn to the Clark and Rowlinson (2004) article that initiated the historic (wrong) turn, for example, we find that - despite the declaration that the "historic turn" is part of a "transformation" that includes "deconstruction" - the article is devoid of references to Derrida, Emmanuel Levinas or Roland Barthes, the central figures in "deconstructionist" theory. Despite emphasizing "discursive" understandings, the article is bereft of references to Foucault. In terms of theoretical underpinnings, Clark and Rowlinson (2004, pp. 331, 347, endnote 2) instead rely upon a book chapter by Brian Fay (1998). Nowhere are we appraised either of the criticisms of such understandings nor the reasons as to why we should set such critiques aside.

The remainder of this article will comprise four sections. In the first, we look at the intellectual roots of the historic (wrong) turn in the idealist philosophies of Nietzsche, Croce, Foucault, White and Latour. In the second section we examine the critiques that have been made of those theories from within "critical" or "Left" theoretical frameworks that are conveniently ignored by the exponents of the historic (wrong) turn. In the third section we will critique the Foucauldian genealogy of the historic (wrong turn), and the ways in which it has been expressed 
in the work of Rowlinson and his various co-authors. In the final section, we will return to an examination of ANTi-History and its flawed foundations in the ideas of Latour.

\section{Theoretical roots of the historic (wrong) turn}

In looking for the "historic turn's" intellectual roots we can ascertain a deep heritage in nineteenthcentury German idealist philosophy - most particularly in Friedrich Schelling (1809/2006) and Arthur Schopenhauer (1859 / 1969) - an intermediate heritage primarily built around Nietzsche and Croce, and a recent intellectual ancestry constructed around Jacques Derrida, Roland Barthes and, above all, Foucault, White and Latour. Although the works that comprise the deep heritage of the "historic turn" are never cited by its proponents, this ancestry nevertheless had a profound influence on Nietzsche and Croce, and through them on Derrida, Foucault and White. All of these philosophers not only shared Schopenhauer's (1859 / 1969, pp. 3,5) belief that "the whole of this world" is "representation", they also held to Schelling's (1809 / 2006, p. 33) view favoring the "complete freedom" of individual consciousness, being and action against all constraints. It was this total and utter emphasis on individual freedom, and its capacity to move beyond all imposed constraints, which became the defining hallmark of Nietzschean philosophy. When, therefore, Nietzsche (1883/1970: 299) indicated in Thus Spoke Zarathustra that, "Man must grow better and more evil," he was asserting freedom of individuality beyond the constraints of the social world, rather than the evil per se. Through the medium of Nietzsche and Croce this advocacy of untrammeled freedom found its way into the philosophy of Foucault and White and, hence, the "historic turn". As White (1963, pp. 121-122) accurately noted in his first significant publication - "The abiding relevance of Croce's idea of history" - "All of Croce's "conception of liberty" revolved around the "rejection" of any institutionalized restraint. Like Schelling and Nietzsche, Foucault also argued throughout his entire career that whatever empowered the individual will was good and whatever restrained it was bad. As Foucault (1961/ 1965, p. 9, 221) expressed it in his first major book, Madness and Civilization, by communicating with "each other through the merciless language of non-madness" the modern world had suppressed "the lyricism of protest", thereby losing its appreciation of "desire and murder, of cruelty and the longing to suffer". In perusing the "historic turn" literature we find constant echoes of this deep intellectual heritage. As with Schopenhauer (1859 / 1969, p. 3), who argued that "the whole of this world" is "representation", Durepos and McLaren (2019, p. 5) declare that, "the social world only exists only as names, ideas and labels." In an echo of Schelling, Nietzsche, Croce, Foucault and White, we are informed by Durepos, Shaffner and Taylor $(2019$, p. 11, 9) that, "Emancipation is understood as ... freedom from constraints", be they institutional or conceptual. 
If the "historic turn's" subterranean foundation finds expression without direction citation, the exponents of this literature also rarely cite Nietzsche or Croce, even though these intermediaries directly shaped the thinking of Foucault and White, and hence their own arguments. Becoming a life-long exponent of Nietzschean philosophy after a summer spent reading Nietzsche in 1953 (Miller, 1993), the influence of the German philosopher on Foucault's thinking is most obvious in his essay, "Nietzsche, Genealogy, History". Of the 55 references to a literary source in the essay, 54 cite Nietzsche. As with Nietzsche (1871, pp. 26, 28), who argued that fact-based history "cripples the active man" and that "great things ... never succeed without some delusion", Foucault's (1971 / 1984, p. 96) essay argued that the historian facilitates the "liberation of man by presenting him with other origins than those in which he prefers to see himself." The Nietzschean underpinnings of Foucault's theory of genealogy / history is also evident in the conclusion of The Order of Things. In attacking "positivism", Foucault (1966 / 1994, p. 322) argued that, "It is easy to see why Nietzsche's thought ...has for us, such a disturbing power" due to his "Promise-Threat" ... that man would soon be no more - but would be replaced by the Superman", a totally new expression of unrestrained individuality. To reach this nirvana, Foucault argued, as did Nietzsche, that accepted restraints and understandings had to be dismantled. For, as Foucault (1972, p. 544) explained it, the human condition "does not begin with freedom, but with the limits and the line that cannot be crossed". Across his career, Foucault identified ever more manifestations of oppression - the "fundamental codes of a culture" (Foucault, 1966 / 1994, p. xx), "discourse" (Foucault, 1970 / 1981), the "disciplinary" society with its "infinitesimal surveillances" (Foucault, 1975 / 1991, p. 308), "biopolitics" (Foucault, 1976 / 1978). What remained constant was the theme that individual freedom is trapped within oppressive norms, prominent among which was the "will to truth", the beliefs that support dominant forms of power (Foucault, 1970 / 1981, pp. 52, 55). Accordingly, in Nietzschean fashion, Foucault (1969 / 1972: 8-9, 25) urged the historian to become an Anti-Historian, thereby causing understandings of the past to be "known, forgotten, transformed, utterly erased."

Significantly, Nietzschean understandings were also central to Hayden White's model of historical writing, White devoting one of the eight studies contained within his defining work, Metahistory, to Nietzsche, declaring, "Friedrich Nietzsche marked a turning point [in historical writing], for he ... denied the reality of any such thing as a historical process." In doing so, White (1973a, pp. 332, 371) continued, Nietzsche not only destroyed "belief in a historical past", he also created "a second illusionary world", a world where history can be remade as one wills. Where White differed from Foucault, however, as we noted in our introduction, was in finding his principle source of inspiration from Croce rather than Nietzsche. Certainly, if we look to Croce's 
understandings, we can ascertain almost all of the viewpoints that historians associate with White. Like White, Croce $(1915$ / 1921, pp. 19, 12) believed that "history is principally an act of thought", a construct of the historian. As the experiences of the past are irreparably lost, any reconstruction has to be based on "documents" that are nothing more than "narratives", recorded by some past interest group (Croce, 1915 / 1921: 21, 23). Accordingly, Croce (1915 / 1921: 75, 69) argued prefiguring White - because what we think of as "facts are no longer facts ...we are free to conceive 'history' as we please." For his part, White, in outlining his own theory in "The Burden of History", put forward arguments barely distinguishable from those of Croce. Calling for "the destruction of the conventional historian's conception of history", (White, 1966, pp. 114, 127) advocated in its place a "surrealist, expressionistic, or existentialist historiography". In doing so, White $(1966$, pp. 131, 130) ridiculed conventional historians for their obsession as to "the facts", arguing that the historian has to behave "like the artist", ordering their narrative around metaphors and "the purely imaginary". In building upon these propositions in Metahistory, (1973a, pp. 1-2) also argued that the "character of historical representation" is inherently "fictive".

Mediated through Foucault and White the understandings of Nietzsche and Croce have done much to inform the direction of the "historic turn". As with Croce (1915 / 1921, p. 55), who declared that that what we think of as history is a mere "imaginative projection" - what White (2005, p. 333) subsequently called "a place of fantasy" - so Durepos and Mills (2011, p. 235) record that, "There is no reality-correspondent 'truth' of the past". Instead, historical "truth" is imaginatively constituted through "words". Whereas Nietzsche (1874, pp. 1-2) declared that each "human being" is only freed "for life and action" when they are liberated from the "burden of the past" - with White (1966, p. 133) supposing that "the burden of the historian is to free men from the burden of history" - so Durepos, Shaffner and Taylor $(2019$, p. 8, 11) call for the "re-writing" of the "past-as-history" so as "liberate" those bound by the "constraints" imposed by "their past", to "show how it [history] could be otherwise and what that otherwise might be" [emphasis in original]. Similarly, we observe how Nietzsche's (1871, p. 25) observation that, "You can interpret the past only on the basis of the highest power of the present", finds an echo not only in Foucault (1971 / 1984, p. 86) - who declared that the "successes of history belong to those who are capable of seizing" it, using it to alter social "rules" - but also in Cummings et al. (2017, p. 41), who declare their New History of Management to be a Foucauldian-inspired "counter-history", written in ways that overturn "accepted continuities and discontinuities" about management. 


\section{Unacknowledged Problems}

If the idealist understandings of Schelling, Schopenhauer, Nietzsche and Croce underpin the ideas associated with the "historic turn" and its various sub-streams, it is also the case those sources that directly inform this literature - most particularly Foucault, White and Latour - are invariably cited in uncritical fashion.

In the case of Foucault, enthusiasm for his ideas in management and organizational studies was apparent long before Clark and Rowlinson's call for an "historic turn". Indeed, in their embrace of Foucauldian concepts the advocates of the "historic turn" were comparative laggards, the pioneering role being occupied instead by Gibson Burrell, who published three Foucauldianinspired articles in Organization Studies between 1984 and 1988 (Burrell, 1984, 1988; Cooper and Burrell, 1988). In these studies, Burrell embraced a Nietzschean / Foucauldian view of history, declaring, "there is no unity in history, no unity in the subject, no sense of progress" (Burrell, 1988, p. 223). Over the ensuing decade a stream of Foucauldian-inspired books appeared in management and organizational studies: Hassard and Parker's (1990) Postmodernism and Organizations, Boje, Gelpert and Thatchenkery's (1996) Postmodern Management and Organization Theory, Roy Jacques's (1996) Manufacturing the Employee and McKinlay and Starkey's (1998a) Foucault, Management and Organization Theory. What this first generation of Foucauldian proponents found most attractive in Foucault was not so much his Nietzschean emphasis on discontinuity but rather, as McKinlay and Starkey (1998b, pp. 3, 5) recorded, his depiction of modern society as one modelled on the "Panopticon penitentiary". In an essay penned in 2003 - a year before the call for a "historic turn" - Clegg and Kornberger (2003, p. 84) similarly described modern organizations as "iron cages" and "psychic prisons".

If the "historic turn" advocated by Clark and Rowlinson - and reiterated in a subsequent chapter by Rowlinson (2004) and in Booth and Rowlinson's (2006) inaugural editorial to Management \& Organizational History - differed from these earlier studies in more explicitly advocating an historical agenda, it also entrenched an uncritical adoption of Foucauldian concepts. As noted earlier, Clark and Rowlinson's (2004, p. 347) article was bereft of direct references to Foucault, even as it declared that, "Jacques' Foucauldian history of the employee" and "Burrell's excursion into Pandemonium" were representative "of the variety [of history] that we would include in an historic turn". Similarly, in Booth and Rowlinson's (2006, p.10) editorial in Management \& Organizational History it is blandly stated that, "If there is to be methodological reflection and experimentation in historical writing, then this will involve further engagement with ... historical theorists" such as White, Foucault and Paul Ricoeur without any acknowledgement 
as to potential problems in using such approaches. In Godfrey et al.'s (2016) article, "What is Organizational History", the same practices are evident. Grandiosely declaring that "the historic turn" represented the birth of an "explicitly theoretical approach to history", Godfrey et al. (2016, pp, 593, 599) heap praise on a bevy of Foucauldian-inspired historians - John Hassard, Charles Booth, Stephen Cummings, Todd Bridgman, Michael Rowlinson - as exemplars of a new theoretically-informed approach to history. The article is, however, devoid of reference to Foucault himself. Even where allegiance to Foucauldian ideas is acknowledged, as in in Cummings et al.'s (2017, p. 35) A New History of Management - where the authors declare themselves to be "inspired by a Foucauldian approach" - there is no attempt to acquaint the reader either with the problems that this may entail or well-known criticisms of Foucault's approach.

Among all the acclaimed researchers associated with the "historic turn" this author is aware of only one article (Rowlinson and Carter, 2002) that attempted a serious appraisal of Foucault's work. Strangely, one of the authors of this article - published two years before Clark and Rowlinson's (2004) call for a "historic turn" - was Rowlinson, the "historic turn's" principal advocate. Among the accurate criticisms of Foucault's work made by Rowlinson and Carter (2002, pp. 543, 534, 532) were the following points: that if "we follow Foucault's" model for understanding history "then it becomes increasingly difficult to invoke history to sustain social theory", that in reading "Foucault's histories, one could be forgiven for thinking that his is the only interpretation, since it pretends not [to] be an interpretation", that Foucault denied "the distinction between coherence / incoherence". As far as this author is aware, none of these criticisms was repeated in any subsequent study associated with the "historic turn". Significantly, proponents of the historic (wrong) turn have eschewed criticisms of Foucault even when they have come from researchers ensconced within the canon of postmodernist and existentialist thought. In one of the earliest English-language assessments of Foucault's work, Hayden White (1973b, pp. 30-31, 38), for example, observed that Foucault rejects "all causal explanations, of whatever sort", that Foucault's first major historical work (Madness and Civilization) was "a rambling discourse" constructed "from a very limited body of data". Among postmodernist thinkers, Derrida made some of the most damning criticisms of Foucault's work. Of Foucault's Madness and Civilization, Derrida (1967 / 2001, pp. 49, 69-70) observed that Foucault's claim to have a unique insight into "the concept of madness" was a patent absurdity. In a subsequent critique of The Order of Things, Derrida (1968 / 1982, p. 119) lambasted Foucault for venturing into areas in which he had little understanding, noting a propensity to "read ... a text poorly, or simply not at all" while laying claim "to great ingenuousness". It was, however, Jean-Paul Sartre, who arguably made the most devastating critique of Foucault's claim to have unique insights into the writing of history as 
genealogy. Although Sartre (1966 / 1971, p. 110) conceded that Foucault's approach "remains historical", he nevertheless condemned him as a person devoid of "true original thought". For the fundamental problem with Foucault's philosophy, Sartre (1966 / 1971, p. 110) correctly observed, was that he was incapable of understanding the factors that caused "thought" to be "constructed" out of lived "conditions" or to move from one set of beliefs to another. Instead of a real, vibrant depiction of history, Foucault merely provided "a magic lantern" in which actual "movement" was transformed into "a succession of immobilities".

If we turn our attention from Foucault to White, we see the same mode of behaviour among proponents of the "historic turn". In endorsing the view that historical narratives are "fictive" constructs, Rowlinson, Hassard and Decker (2014, p. 151), for example, declare White to be "a leading philosopher of history". Similarly, Durepos (2015, p. 153) ranks White alongside Foucault in terms of his importance "to the development of postmodern historiography". Yet, as with Foucault, White's name and concepts are hailed without acknowledgement of the criticisms that have been made of his ideas even within "critical" or postmodernist historiography. Marilyn Waldman (1981, pp. 785, 791), for example, in one of the earliest critiques of White's work, condemned "his fundamental" Eurocentrism, accurately noting that his "distinctions" between "historical and fictional narrative" were "drawn from essentially Eurocentric research". In 2005 a more significant attack was mounted by the critical theorist, Dirk Moses (2005, pp. 314), who correctly surmised that, "White thinks that national or ethnic mythologies are a legitimate use of the past insofar as they an answer to the burden of history." The problem, Moses noted (2005, pp. 314-315), was that such mythology was used to justify "unspeakable atrocities" committed by "ethnic groups and nationalizing states". The main controversy that dogged the latter half of White's career, however, related to the veracity or otherwise of the Holocaust with White suffering attacks from both Lang (1995) and Ginzberg (cited Paul, 2011, p. 121) as to whether or not the Holocaust was merely "fictive", "an imaginative creation", as was claimed by his close supporter, Hans Kellner (1998, p. 237). Despite devoting an entire chapter of The Practical Past to this debate - in which he stated "that we cannot establish on the basis of any strictly factual account whether the Holocaust was a new event, a new kind of event or...an event peculiar to our modernity" (White, 2014, p. 38) - White never successfully answered his critics on this point. Yet, despite the fact that this problem clearly troubled White himself, none of the exponents of the "historic turn" have ever even acknowledged White's conceptual difficulties on this score.

Among the theoretical models embraced by the "historic turn's" sub-strands, none is arguably more problematic than ANTi-History, the conceptual model constructed around the ideas 
of Bruno Latour. For, to an even greater degree than was postulated by either Foucault or White, Latour's Actor-Network Theory (ANT) argues that "facts" and "reality" can only be understood as socially constructed "fictions". As Latour and Woolgar (1979 / 1986, pp.180, 182, 236, 106-107) explained in Laboratory Life, the pioneering study that gave rise to ANT: "reality" cannot "be used to explain why a statement becomes a fact, since it is only after it has become a fact that an effect of reality is obtained", that every "fact" is merely "an artefact" created and sustained by an actornetwork, that in "a fundamental sense" every account of "reality" is "a fiction", that "historical accounts are necessarily literary fictions". Elsewhere, Latour (1997 / 2000, p. 126) informs us that the key to understanding the success of a scientific theory is to be found not in evidence but only through a determination as to which actor-networks "are stronger" (Latour, 1988, p. 24).

Originally postulated as a theoretical framework for understanding scientific research, Latour's ideas were soon repudiated in scientific circles. In the "Introduction" to the second edition of Laboratory Life, Jonas Salk (1979, p. 13) - who had allowed Latour into his laboratory declared serious "doubts" as to Latour's conclusions, noting that "many details" of what Latour purported to describe did "not fit" his own observations. In a harsher assessment, Sokal (1997 / 2000 , p. 128) observed that, "Latour purports to address issues of the sociology of the sciences, but his exposition is confused: he mixes up ontology and epistemology, and he attacks positions that no one would defend." The accusation that Latour was a confused charlatan is also found in Sokal and Bricmont's (1997 / 1998, pp. 92, 96) Fashionable Nonsense, where it is recorded that Latour's arguments are "either true but banal, or else surprisingly but manifestly false", and that, "Latour is playing constantly on the confusion between facts and our knowledge of them."

Confusion as the difference between facts (e.g. the Nazi regime operated a concentration camp at Dachau between 1933 and 1945), evidence (e.g. Nazi camp records) and interpretation (e.g. why German society tolerated concentration camps) is characteristic of not only the youthful Latour's work. It also characterizes what has become known as ANTi-History. Thus, we read (Mills, Weatherbee and Durepos, 2014, p. 235) that there "is no reality-correspondent 'truth' of the past", that "the past comes into being through the associations and translations of actors as they engage in doing history [emphasis in original] (Mills and Durepos, 2011, p. 711). From an ANT perspective, "objective" knowledge of things past is impossible because "texts" and other evidence of the past are "actants", socially-created "inscriptions" that are merely constructs within an network-actor (Latour, 1987; Durepos and Mills, 2012). In other words, every source of historical evidence that we may consider is the result of some self-interested actor-network. Containing a measure of truth when we consider one sort of evidence - i.e. textual records left in 
the form of diaries, company and trade union archives - the fundamental premises of ANT are nevertheless as confused in relation to the discipline of history as they are in relation to the natural sciences. For, as the Marxist, E.P. Thompson (1978, p. vi) observed, arguments suggesting that "historical evidence comprises only those words which ... actors intended to transmit to posterity" are "half-truths: which is to say, they are untrue. By far the greater part of historical evidence has survived for reasons quite unrelated to any intention of the actors", namely "the records of administration, taxation ... and the archaeological evidence" [emphasis in original].

Such are the problems of arguing that all evidence is a social construction that in the end even Latour - increasingly obsessed about the perils of climate change - abandoned many of his earlier positions, realizing that it is impossible to argue that climate change is a reality while claiming that all evidence is fictive. Lamenting the results of his earlier assertions, Latour (2003, pp. 226-227) noted that "entire Ph.D. programs" were teaching students "that facts are made up, that there is no such thing as natural, unmediated, unbiased access to truth." Despite such acknowledgments, none of ANTi-History's exponents have to-date even acknowledged the wellversed criticisms of their premises.

\section{Mislabeling, Confusion and the Historic (Wrong) Turn}

In a recent article entitled "Re-visiting the Historic Turn 10 years later", Mills et al. (2016, p. 67) accurately observed that the "historic turn ... is perhaps mislabeled", and that perceiving it as reengagement with history "very much depends on what is seen as history". The nebulous nature of the "historic turn" is also indicated by Durepos, Shaffner and Taylor (2019, pp. 1, 6), who contrast "the original definition of the historic turn" - which they associate with "reflexible accounts" that underpin "leftist' progressive ideological commitments" - with its (subsequent) advocacy of more generic understandings of historical research.

The mislabeling and confusion surrounding the "historic turn" is inherent in the ways in which it has been variously presented. As noted in the introduction, Clark and Rowlinson's (2004, p. 331) original article linked their "historic turn" to the "wider transformation ... alluded to in terms such as the 'discursive turn', deconstruction and post-modernism." In doing so, however, Clark and Rowlinson avoided direct references to any well-known postmodernist philosopher, thereby allowing a casual (mis)reading of their call as merely one directed towards greater engagement with history per se. Such a (mis)reading was facilitated by Clark and Rowlinson's (2004, p.334) observation that, 
While an historic turn may be congruent with some of the ontological and epistemological positions within Critical Management Studies, it is by no means exclusive to a radical political position ... arguments against determinism in history are by no means limited to leftists ... conservative and liberal historians, such as Ferguson, are among the avowed opponents of determinism

This bipolar characterization of the "historic turn" - in which it was depicted as both postmodernist critique and something capable of being embraced by Niall Ferguson - has, if anything, become more pronounced over time. In an article sub-titled "The Continuing Historic Turn", Rowlinson (2013, p. 327), for example, associated "the progress of the historic turn" with simply "the increasing receptiveness of the generalist journals in management and organization theory to historical studies." Similarly, Peter Miskell (2018, p. 213), the editor of Management \& Organizational History, describes the "historic turn" as simply "a process in which history and theory meet on equal terms." In a Special Issue of the Journal of Management History, Van Lent and Durepos (2019, p. 429) also primarily associated the "historic turn" with "the importance of history to understanding organizational life", a position that no historian would oppose. By contrast, however, when we examine the actual work written by the main proponents of the "historic turn" - as exemplified in Booth and Rowlinson's (2006) editorial in Management \& Organizational History, the special issue in Management \& Organizational History led off by Rowlinson and Hassard (2013), the special issue in Management \& Organizational History in introduced by Mills et al. (2016), The Routledge Companion of Management and Organizational History edited by McLaren, Mills and Weatherbee (2015), the special issue in Academy of Management headed by Godfrey et al. (2016) and Cummings et al.'s (2017) A New History of Management - then we witness something different: perceptions of "history" and historical writing that are (variously) rooted in the ideas of Foucault, White, Latour and, to a lesser degree, Ricoeur and Derrida. Drawing on these understandings, Durepos, Shaffner and Taylor (2019, pp. 1-2) associate "the original definition of the historic turn" with "rejection of scientism" and a "shift away" from "empiricist positivism". That the original "call for a historic turn" was rooted in predominately Foucauldian precepts is also indicated by Rowlinson's (2004) chapter entitled “'Historical Perspectives in Organization Studies: Factual, Narrative, and Archaeo-Genealogical".

Mislabeling and confusion in relation to the "historic turn" also reflects a tendency of its proponents to espouse positions in ways that suggest that their interpretations are accepted historical wisdom. As noted earlier, Rowlinson, Hassard and Decker (2014, p. 151) declare White to be "a leading philosopher of history" when in actual fact he was, by his own admission, an anti- 
history historian who believed that humanity had to be freed from "the burden of history" (White, 1966, p. 133). In similar fashion, Van Lent and Durepos (2019, pp. 429, 431) declare that "the historical discipline provides an alternative to the dominant science paradigms in organization studies", when in truth many (if not most) historians still believe in the value of thesis generation and testing. Advocates of the "historic turn" also associate their own perspectives with an embrace of "pluralist" rather than "unitary" models (Miskell, 2018; Drucker, Kipping and Wadhwani, 2015). There are two inferences here, both of them inaccurate. The first inference is that all historians who do not share a critical / postmodernist perspective are "positivists" bound by a common but narrow mindset. In truth, as we noted in the opening paragraph of this article, the discipline of history has always been pluralist, sharing a wide variety of epistemological and political positions. The second inference is that the "historic turn", and the wider body of critical / postmodernist opinion, is open to "conservative" historians (Clark and Rowlinson, 2004, p. 334). In reality, the battle lines between postmodernist and non-postmodernist epistemologies are drawn around irreconcilable differences as to not only evidence but also as to the nature of "reality"; differences that are rooted in long-standing differences between idealist philosopher-historians (Carlyle, Nietzsche, Croce) and realist philosopher-historians (Hume, Marx, Thompson). We should also not infer, as Durepos, Shaffner and Taylor (2019, p. 6) do, that a postmodernist / anti-realist perspective is a precondition for the enactment of "a leftist ideology". On the contrary, there are many Marxists and "Left" activists - including Sartre (1966 / 1971), Callinicos (1995), Sokal (1997 / 2000) - who have fought tooth-and-nail against postmodernism. As Sokal (1996 /2000, pp. 250, 252), expressed it, far from being an essential platform for a "leftist" challenge, postmodernist "relativist philosophies" undercut the Left's capacity to produce "a realistic analysis of society that ... our fellow citizens will find compelling."

At a theoretical level the nebulous cloud associated with the "historic turn" - in which it sometimes appears to embrace history per se and at others times uproot historical understandings - stems from the already noted habit of utilizing postmodernist understandings without much (if any) acknowledgement. At one level this approach allows proponents of the "historic turn" to appear as "pluralists". This, "pluralism", however, comes at the cost of intellectual consistency as authors combine concepts in ways akin to mixing water and oil. White (1966, pp. 130-131), for example, argued that it is the historian who creates not only history and knowledge, but also reality, a position reflected in McLaren and Durepos's (2019, p. 5) claim that, "Social reality is constructed out of our efforts to define it." This is a very different argument to that of Foucault (1976 / 1978, pp. 100-101) who recorded that, "it is in discourse that power and knowledge are joined together", and that discourse is "both an instrument and an effect of power". 
In other words, the historian operates within a network of power and discourse that is externalized as well as internalized. White's highly subjectivist understanding of knowledge - grounded as it is in Croce - is also incompatible with Latour's ANT framework. For the fundamental premise of Latour's ANT is that knowledge is wholly the social creation of an actor-network, and that there is no such thing as knowledge outside the actor-network. In other words, the historian is either part of an actor-network, or they are rendered mute and powerless.

If we are to sum up the core theoretical constructs associated with the "historic turn", we can ascertain four main features. First, with the notable exception of ANTi-History - to which we will return in the next section - there is little evidence of theoretical originality. Instead, the core propositions argued are largely derived from Foucault and White, whose guiding intellectual positions were obtained from Nietzsche and Croce. Second, to the extent that there is theoretical originality it largely results from mislabeling and confusion rather than from any new insight into either the nature of knowledge or the dynamics of modern organizations and management. As noted in the previous paragraph, this has seen different epistemologies combined with little apparent awareness and / or concern as to the differences that the various explanations entail. Third, there is a tendency to confuse ontology (i.e. the nature of being) with epistemology (i.e. the ways in which we understand the nature of being). To argue in favor of radical "ontological nominalism", that "the social world exists only as names, ideas and labels", as McLaren and Durepos $(2019$, p. 5) do, is inconsistent with claims that a "leftist ideology" can change the lived experiences of the populace (McLaren and Durepos, 2019, p. 7). In other words, one cannot hold to a nominalist or idealist ontology that denies the objective nature of being whilst, simultaneously, identifying a response grounded in realist ontology. The fourth defining characteristic of the "historic turn" literature is misrepresentation, a willingness to describe one's own chosen positions as "pluralist" while lumping every opposing epistemological position together under headings such as "positivist" and "unitarist".

\section{ANTi-History: A Problematic Path}

Intellectually nebulous, the so-called "historic turn" has, as we have previously observed, witnessed the emergence of various sub-currents. Of these, ANTi-History - a theoretical framework derived from Latour and pioneered by Durepos and Mills $(2011,2012)$ - is the most significant and also the most problematic. In adopting an ANTi-History approach, de Sá and de Costa (2019, p. 496), for example, proclaim its "emancipatory capacity ... its ability to legitimate multiple accounts of the past." Similarly, Marshall and Novicevic (2016, p. 99) laud ANTi-History's "innovative approaches which problematize the relationship between the past and history". 
Coraiola, Foster and Suddaby (2015, p. 218) likewise praise ANTi-History for its supposed ability to "uncover and expose the different ontological positions of professional history producers". Even Jeffrey Muldoon $(2019,2020)$, one of only three academics to pen a critical appraisal of the "history turn" literature - the others being Batiz-Lazo (2019) and myself (Bowden, 2018) acknowledges that, "ANTi-History is one of the most ambitious attempts by management historians and historians in general to develop a framework to describe how history is made" (Muldoon, 2020, p. 12).

Conceptually, ANTi-History, as we have noted previously, draws on Latour's ANT and is built around three key propositions. First, in an apparent accommodation with "realism", Durepos and Mills (2011, p. 710), accept the objective existence of a lived past, declaring that "what we lived and now call the past is not to be denied, nor what we wish to contest"'. However, having made this point, Durepos and Mills (2011, pp. 712, 716), then proceed to advocate a subjective and idealist epistemology, arguing "that history and knowledge" are socially constructed by the actor-network's "effort to define it". In ANTi-History, this understanding as to the social construction of "reality" - or, rather, the perceptions that the actor-network socially constructs as "reality" or "history" - extends not only to historical analysis but also to evidence. According to both Latour (1987) and Durepos and Mills (2012, p. 101), all forms of evidence are merely "actants", or "non-human actors", that are as just as much part of an actor-network as the political ideologue. In other words, everything that we know and can know is subjective rather than objective, the creation of some self-interested actor-network. As such, Durepos and Mills (2011, p. 712) make claim to a more subjectivist epistemology (and ontology) than either Derrida or Foucault, arguing that both erred in assuming "their phenomena as already constituted"; a position that they identify as "diametrically different" to their own. ANTi-History's third key proposition is that "history", as a social construction, is a malleable product and that the historian has "an active political choice in representation" [emphasis in original] (Durepos and Mills, 2011, p. 716). As such, historians do not write or interpret history. Rather they "do history", actively creating what we understand to be the lived reality of the past. Seen from this perspective, not only is it impossible for a historian to be "objective", it is also the case that the historian should write history so as to reshape the future. Therefore, for the ANTi-Historian, so Durepos, Shaffner and Taylor (2019, p. 8) explain, "Doing history" should be a task directed towards revealing how history "could be otherwise" than what has been understood "and what the otherwise might be".

In assessing ANTi-History, Muldoon makes two criticisms, both of which I endorse. First, Muldoon (2020, p. 12) observes that Durepos and Mills reveal "a conspiracist view of the world" 
in terms of evidence, assuming that evidence only exists because of networks seeking to win over adherents to their own world view. As Muldoon notes, this assumes that actor-networks operate with a level of foresight that belies the nature of the human condition, whereby short-term activities and interests preoccupy behavior. Nowhere is this arguably more so than in business and management, where a firm's long-term survival depends in the first instance on its success or failure in day-to-day activities. In these short-term activities a firm always generates a documentary trail that is distinct from any records that it may or may not choose to deposit in an archive: sales records, tax payments, purchases, output figures, employee hiring, etc. For management historians such accounts of day-to-day activities can be far more revealing than what is officially recorded in annual reports, newsletters and the like. Among still-practicing management historians, the arguable master of this type of research is James Wilson, the current Past Chair of the Management History Division of the Academy of Management. In the case of the Ford Motor Company, Wilson $(2014,2015)$ overturned decades of accepted wisdom in relation to the supposed "inflexibility" of Ford's production methods by revealing that production was constantly varied so to match sales-orders, rather than sales-orders following on from predetermined production. If Muldoon is justified in making the claim that ANTi-History has a "conspiracist" of evidence, there is also merit to his criticism that there "are numerous times when people act against their network" - and indeed their own self-interest - because evidence convinces them that accepted wisdom is in error (Muldoon, 2020, p. 13). Although there are countless proofs of Muldoon's maxim, perhaps the most famed is found in the publication of Copernicus's De Revolutionibus (On the Revolutions), a work that Copernicus only published on his death-bed because of the wrath he knew he knew it would generate within the society's dominant actor-network: the Catholic Church. Gaining nothing from his publication, Copernicus (1541 / 2008, p. 4) was nevertheless driven - as he explained in his book's preface - by the belief that every "philosopher" should "seek the truth in all things, to the extent permitted to human reason by God".

While endorsing Muldoon's criticisms, I also suggest that Durepos and Mills made four more substantive errors in developing ANTi-History, each of which stems from the theory's underpinnings in Latour's ANT framework. First, the observation that Sokal (1997 / 2000, p. 128) made in relation to Latour's ANT framework - that "he mixes up ontology [i.e. the nature of being] and epistemology" (i.e. the ways in which we understand reality and being) - applies with equal force to ANTi-History. In Latour's (1987, p. 99) work, this confusion of ontology and epistemology is clearly indicated in his Science in Action, where he argues: "Since the settlement of a controversy is the cause of Nature's representation ... we can never use the outcome - Nature - 
to explain how and why a controversy has been settled." Embracing this inferred nominalist or idealist ontology (i.e. that there is no world outside our subjective understanding), Durepos and Mills (2012, pp. 122-123) likewise declare that ANTi-History is "aligned with ANT" in rejecting "realist ontological assumptions" and that it "assumes that the past has gone and thus cannot be said to exist in a realist ontological sense." The problems with this line of thinking have long been apparent, Lang (1995, p. 89) noting during the debate as to the reality or otherwise of the Holocaust that, "Most people ... would be reluctant to concede that whether they existed five minutes ago depends on what historians ... say about them." Rather than it being the case that past and present are ontologically separate, in reality they blur. I exist now because I existed five minutes ago. The computer that I am typing this article on exists because it is a material artefact of the past. As Braudel (1958 / 2009, p. 182) accurately observed, "The time of today is composed simultaneously of the time of yesterday, of the day before yesterday, and of bygone days." In the case of ANTi-History, the starting point for their analysis is - moreover - not subjective consciousness and being but rather the actor-networks that exist independently of consciousness.

The second error of ANTi-History, and ANT more generally, is that it confuses facts (i.e. something that existed or exists) and evidence (i.e. our knowledge of facts, which is always partial). For, as Marc Bloch (1944/ 1951, pp. 124-125), the problem for the historian, as for all researchers, "exists in us, in our memory, or in that of our witnesses, and not in the things themselves". Memories deceive. Evidence is lost. The historian also often faces the problem of too much evidence. In other words, the historian is confronted with the problem of distinguishing between evidence that is important to their enquiries from that which is ephemeral. In the final analysis, such problems relate to interpretation - the questions we are asking and the hypotheses that we are testing. Put another way, facts - that is evidence to which we attach a high measure of veracity - are anchor points for our narrative. But our narrative is interpretation, something that is tentative and subject to revision.

ANTi-History's third conceptual failing is that, like the youthful Latour, it makes the actornetwork the decisive factor in the construction of knowledge, rather than evidence. As Durepos and Mills (2011, p. 715) explain, "a central critical element" of ANTI-History is that "history" results from the interest-driven politics of actor-networks" [emphasis in original]. For the historian, this supposedly demands "reflexivity", an awareness as to "active political choice ... whereby certain facets of the history's construction will feature at the expense of others". Now, few people will disagree with the argument that politics are a factor in the success or otherwise of an argument, or that research can have a socioeconomic effect. Where one departs from the ANTi-History 
argumens is in the supposition that politics - that is, the interests of the actor-network - are, or should be, the only factor in interpretation; that "the actor-network should", as Durepos and Mills (2011, p. 712) suggest, "speak louder than the voice of the trained historian." For to follow this line of argument results in the transformation of the historian into an ideologue, pure-and-simple. This is not to say that the historian is not affected by political biases. However, as historians and, indeed, as human beings - our opinions tend to be correlated with evidence. We support free-market capitalism because of the wealth it produces. Or, alternatively, we oppose free-market capitalism because of the inequalities it generates. As new evidence emerges, people's opinions shift. Many Marxists, for example, abandoned their commitment to socialism after the fall of the Berlin Wall, when the problems of the old Soviet bloc were laid bare.

The fourth, and in many ways defining, problem of ANTi-History - a problem that it shares with the wider "historic turn" literature - is in arguing that the historian's task should be driven by "their socio-politics" (Durepos and Mills, 2011, p. 711), that "doing historical research is an impactful vehicle to enact a leftist ideology (Durepos, Shaffner and Taylor, 2019, p. 6). Such arguments are at odds with the traditional premises of scholarship, that the researcher is capable of looking beyond their own preconceived notions to be guided by the evidence. Such premises should be - indeed, need to be - the basis from which not only every management historian operates but also every scholar interested in management. As Anita McGahn (2019, p. 253) noted in summing up her time as President of the Academy of Management, "the essence scholarship and of a scholarly stance is to bring our best intelligence and full selves to discern the truth." In my view, it is these principles that should continue to guide us.

\section{Conclusion}

The product of a Detroit working class family, in 1968 Hayden White edited a book dedicated to William Bossenbrook, the Wayne State professor who first interested him in history. In penning an essay for this collection, White $(1968$, p. 55) called on historians to be flagbearers in a movement to undercut all forms of authority, arguing that "social institutions, ideas and values" were all "barriers" that had to be overturned in the quest for unrestricted freedom. Arguably, it is this opposition to all forms of authority - including accepted historical understandings and epistemologies - that exponents of the "historic turn" find most attractive. Certainly, in the article that launched the so-called "historic turn", Clark and Rowlinson (2004, pp. 334, 331) argued in favor of "history as flux, with continual crises, conflicts and dilemmas within organisations". Elsewhere within the "historic turn" literature we witness claims that historians need to engage in the "denaturalization" of accepted historical understandings (Durepos, Shaffner and Taylor, 2019, 
p. 8), that history needs to become a Foucauldian "counter-history" that "overturns accepted continuities and discontinuities" (Cummings et al., p. 41).

Widely hailed, this article has argued that the so-called "historic turn" is in fact an historic wrong turn, a turn marked by mislabeling, misrepresentation, confusion and a strange reluctance to even acknowledge - let alone defend - underlying theoretical positions. Instead, we often see advocates of the "historic turn" seamlessly shift from one epistemological position to another in ways akin to a seagull moving from one hot chip to another, uncertain as which one they most favor. In an article in Academy of Management Review, for example, Rowlinson and Hassard joined Decker in declaring support for White's understanding of "history" while declaring that, "we need to have a clear idea of the kind of history we mean" (Rowlinson, Hassard and Decker, 2014, p. 251). Three years later, Rowlinson and Hassard were part of a quartet that boasted a Foucauldian understanding in authoring A New History of Management (Cummings et al., p. 35). In neither study did Rowlinson, Hassard and their co-authors discuss - let alone weigh up - the fundamental differences that characterize Foucault and White's view of "history"'. Yes, it is true, that Foucault (1971 / 1984, p. 88) advocated a Nietzschean view of history, arguing that, "History becomes 'effective' to the degree that it introduces continuity into our very being." However, Foucault (1976 / 1978, p. 101) also argued that history, like all forms of knowledge, was rooted in "discourse", which is "both an instrument and an effect of power". In other words, there is an externality to power, and that in trying to understand the linkages between that externality and discourse we should start from "from historical facts that serve as guidelines for research" (Foucault, 1976 / 1978, p. 13). By contrast, White (2005, p. 333) - whose ideas were almost identical with those previously enunciated by Croce - had a far more subjectivist view of history, declaring, "History's subject matter, that is, the past ... is a place of fantasy." For White, as for Croce (1915 / 1921, p. 73), who argued that "facts really do not exist", the historian is not bound by the constraints of discourse or evidence, but is free to remake history more-or-less as they will.

The holding of confused and contradictory positions is not an accidental by-product of the "historic turn". Rather, it is a defining characteristic of the genre. If we look to Clark and Rownlinson's (2004) original article, for example, we find no references to Foucault, Derrida, White or any other major postmodernist thinker. Nor is there any reference to the long-standing idealist traditions upon which Foucault and White, in particular, drew. Most of White's ideas of history, as he himself freely acknowledged, were drawn from Croce, just as Foucault's historical understanding were derived in large part from Nietzsche. Cut loose from its intellectual origins in nineteenth and early twentieth century thought, the advocates of the "historic turn" proclaim very 
old ideas - that knowledge is subjective, that historical writing should inspire rather than faithfully record, that the past is a lost world - as original understandings. Failing to properly acknowledge the historical origin of their ideas and /or the critiques of those ideas - and misrepresenting all contrary opinion as "positivist" - those associated with the historic (wrong) turn are destined to replicate the conceptual errors of their chosen theoretical champion, even when the problems associated with the champion in question have been known for decades. In criticizing Latour's Actor-Netwok Theory, for example, Sokal (1997 / 2000, p. 128) accurately observed that Latour "mixes up ontology and epistemology", while at the same time confusing facts for the evidence relating to facts. Replicating Latour's errors, Durepos and Mills $(2011,2012)$, along with other proponents of ANTi-History, similarly confuse ontology (i.e. the nature of being) and epistemology (the nature of knowledge), thereby also confusing facts and evidence. For, despite claiming adherence to a "nominalist" ontology - that there exists no reality outside of our subjective consciousness (Durepos, Shaffner and Taylor, 2011) - the advocates of ANTi-History make the actor-network the starting point for their theory of knowledge, i.e. a social network that exists actually and independently of our fancy. Such confusions lead, in turn, to misunderstandings relating to "facts" (i.e. things that exist independently of our fancy), "evidence" (i.e. the medium through which I ascertain knowledge of a fact, be it a full or partial knowledge) and "interpretation" (i.e. the ways in which I connect evidence to explain an historical outcome).

One does not need to be an intellectual conservative or part of the political "Right" to appreciate the problems associated with the ontological and epistemological positions of the "historic turn". Indeed, prior to the ascent of postmodernism, the "Left" always associated the current human condition as one resulting from lived conditions, from historically rooted experiences that left a legacy in terms of ideas, machinery, housing conditions, educational opportunities. For all of us, facing the lived realities of a post-coronavirus world - whether of Left or Right - we need to, once again, make the realities of the human condition the starting point for our inquiries. Unfortunately, for the exponents of the "historic turn" this needs to entail recognition - as Bruno Latour (2003, p. 203) came to recognize in relation to his claims that all knowledge is socially constructed - "that a certain critical spirit ... sent us down the wrong path." 


\section{References}

Batiz-Lazo, B. (2019), "What is new in 'a new history of management", Journal of Management History, Vol. 25, No. 1, pp. 114-124.

Bloch, M. (1944 / 1951), The Historian's Craft, Manchester University Press, Manchester, UK.

Boje, D., Gelpert, R. and Thatchenkery, T. (1996) Postmodern Management and Organization Theory, Sage, London, UK.

Booth, C. and Rowlinson, M. (2006), "Management and organizational history: Prospects", Management \& Organizational History, Vol. 1, No. 1, pp. 5-30.

Bowden, B. (2018), Work, Wealth and Postmodernism: The Intellectual Conflict at the Heart of Business Endeavour, Cham, Switz.

Braudel, F. (1958 / 2009), "History and the social sciences: The longue duree", Review, Vol. 32, No. 2, pp. 171-203.

Burrell, G. (1984), "Sex and Organizational Analysis", Organization Studies, Vol. 5, No. 2, pp. $97-$ 118.

Callinicos, M. (1995), Theories and Narratives: Reflections on the Philosophy of History, Polity Press, Cambridge, UK.

Clegg, S.R. and Kornberger, M. (2003), "Modernism, postmodernism, management and organization theory", Research in the Sociology of Organizations, Vol. 21, pp. 57-888

Cooper, R. and Burrell, G. (1984), "Modernism, Postmodernism and Organizational Analysis", Organization Studies, Vol. 9, No. 1, pp. 91-112.

Copernicus, N. (1541 / 2008), De Revolutionibus (On the Revolutions), http://www.geo.utexas.edu/courses/302d/Fall 2011/Full\%20text\%20\%20Nicholas\%20Copernicus, \%20 De\%20Revolutionibus\%20(On\%20the\%20Revolutio ns), \%201.pdf

Burrell, G. (1988), "Modernism, Postmodernism and Organizational Analysis 2: The Contribution of Michel Foucault", Organization Studies, Vol. 9, No. 2, pp. 221-235.

Clark, P. and Rowlinson, M. (2004), "The treatment of history in organisation studies: Towards an 'Historic Turn'?", Business History, Vol 46, No. 3, pp. 331-352. 
Coraiola, D.M., Foster, W.M. and Suddaby, R. (2015), "Varieties of history in organizational studies". In: McLaren, P.G., Mills, A.J. and Weatherbee, T.G. (eds), The Routledge Companion of Management and Organizational History, Routledge, London and New York, pp. 206-221.

Croce, B. (1915 / 1921), Theory and History of Historiography, George G. Harrap \& Co., London, UK.

Cummings, S., Bridgman, T., Hassard, J. and Rowlinson, M. (2017), A New History of Management, Xambridge University Press, Cambridge, UK.

Derrida, J. (1967 / 2001), Writing and Difference, Routledge and Kegan Paul, New York, NY.

Derrida, J. (1968 / 1982), "The ends of man”. In: Derrida, J. (ed. Bass, A), Margins of Philosophy, University of Chicago Press, Chicago, IL, pp. 111-136.

de Sá, R.G. and de Costa, A.S. M (2019), "In search of transparency: ANTi-History, memorials and resistance", Journal of Management History, Vol. 25, No. 4, pp. 493-515.

Drucker, S., Kipping, M. and Wadhwani, R.D. (2015) “New business histories! Plurality in business history research methods", Business History Review, Vol. 57, No. 1, pp. 30-40.

Durepos, G. (2015), “ANTi-History: Toward amodern histories”. In: McLaren, P.G., Mills, A.J. and Weatherbee, T.G. (eds), The Routledge Companion of Management and Organizational History, Routledge, London and New York, pp. 153-180.

Durepos, G. and Mills, A.J. (2011), "Actor-network theory, ANTi-history and critical organizational historiography", Organization, Vol. 19, No. 6, pp. 703.721.

Durepos, G. and Mills, A.J. (2012), ANTi-History: Theorizing the Past, Hisotry, and Historiography in Management and Organization Studies, Information Age Publishing, Charlotte, NC.

Durepos, G., Shaffner, C. and Taylor, S. (2019), "Developing critical organizational history: Context, practice and implications", Organization, Online First, pp. 1-19.

Elton, G.R. (1967 / 1969), The Practice of History, Collins Fontana, Sydney, AUS.

Foster, W.M., Coraila, D.M., Suddaby, R., Kroezen, J. and Chandler, D. (2017), "Thestrategic use of historical narratives: A theoretical framework", Business History, Vol. 59, No. 8, pp. 1176-1200.

Foucault, M. (1961 / 1965), Madness and Civilization: A History of Insanity in the Age of Reason. Pantheon Books, New York, NY. 
Foucault, M. (1966 / 1994), The Order of Things, Vintage Books, New York, NY.

Foucault, M. (1969 / 1972), The Archaeology of Knowledge, Pantheon Books, New York.

Foucault, M. (1970 / 1981), "The order of discourse: Inaugural lecture at the College of France", In: Young, R. (ed.), Untying the Text: A Post-structuralist Reader, Routledge \& Kegan Paul, Boston, MA, pp. 48-78.

Foucault, M. (1971 / 1984), "Nietzsche, Genealogy, History". In: Rabinow, P. (ed.), The Foucault Reader, Penguin, Harmondsworth, UK, pp. 76-100.

Foucault, M. (1972 / 2001), "Madness, the absence of an oeuvre". In: Foucault, M. (trans. Murphy, J. and Khalfa, J), History of Madness, Second edition. Routledge, London, UK, pp. 541549.

Foucault, M. (1975 / 1991), Discipline and Punish: The Birth of the Prison, Vintage Books, New York, NY.

Foucault, M. (1976 / 1978), The History of Sexuality - an Introduction, Pantheon Books, New Yor, NY.

Godfrey, P.C., Hassard, J., O'Conner, E.S., Rowlinson, M. and Ruf, M. (2016), "What is organizational history? Toward a creative synthesis of history and organization studies", Academy of Management Review, Vol. 41, No. 4, pp. 590-608.

Hassard, J. and Parker, M. (1990), Postmodernism and Organizations, Sage, London, UK.

Hume, D. (1748 / 1902), "An inquiry concerning human understanding". In: Hume, D. (ed. SelbyBigge, L.A.), Inquiries Concerning Human Understanding and Concerning the Principles of Morals, Second edition, Clarendon Press, Oxford, UK, pp. 2-165.

Jacques, R. (1996), Manufacturing the Employee: Management Knowledge from the $19^{\text {th }}$ to the $21^{\text {st }}$ Centuries, Sage, London, UK.

Jacques, R. and Durepos, G. (2015), "A history of management histories: does the story of our past and the way we tell it matter". In: McLaren, P.G., Mills, A.J. and Weatherbee, T.G. (eds.), The Routledge Companion to Management and Organizational History. Routledge, London and New York, pp. 96-111.

Kellner, H. (1998) “ 'Never again' is now”. In: Fay, B., Pomper, P. and Van, R.T. (eds.) History and Theory: Contemporary Readings, Blackwell Publishers, Oxford, UK, pp. 225-244. 
Lang, B. (1995), "Is it possible to misrepresent the Holocaust?", History and Theory, Vol. 34, No. 1, pp. 84-89.

Latour, B. (1987), Science in Action, Harvard University Press, Cambridge, MA.

Latour, B. (1988), "A relativist account of Einstein's relativity”, Social Studies of Science, Vol. 18, No. 1, pp. 3-44.

Latour, B. (1997), "Is there science after the Cold War". In: Lingua Franca editors (eds.), Sokal Hoax: The Sham that Shook the Academy, University of Nebraska Press, Lincoln, NE, pp. 24-26.

Latour, B. (2003), "Why has the critique run out of steam? From matters of fact to matters of concern", Critical Inquiry, Vol. 30, No. 2, pp. 225-248.

Latour, B. and Woolgar, S. (1979 / 1986), Laboratory Life: The Construction of Scientific Facts, Second edition, Princeton University Press, Princeton, NJ.

Marshall, D.R. and Novicevic, M. (2016), "Legitimating the social enterprise: Development of a conformance framework based on a genealogical pragmatic analysis", Management \& Organizational History, Vol. 11, No. 2, pp. 99-122.

Marx, K. (1852 / 1951), "The eighteenth Brumaire of Louis Bonaparte”. In: K. Marx and F. Engels, Selected Works, Vol. 1, Foreign Languages Publishing House, Moscow, USSR, pp. 225326.

McGahn, A.M. (2019), "My presidency of the Academy of Management: Moral responsibility, leadership, governance, organizational change, and strategy", Journal of Management Inquiry, Vol. 28, No. 3, pp. 251-267.

McKinlay, A. and Starkey, K., eds. (1998a), Foucault, Management and Organization Theory, Sage Publications, London, UK. B

McKinlay, A. and Starkey, K. (1998), "Managing Foucault: Foucault, management and organization theory". In: McKinlay, A. and Starkey, K. (eds.), Foucault, Management and Organization Theory, Sage Publications, London, UK, pp. 1-13.

McLemee, (2018), "Essay on the death of Hayden White", Inside Higher Ed, https://www.insidehighered.com/print/views/2018/03/09/essay-death-hayden-white

Miller, J. (1993), The Passion of Michel Foucault, Simon \& Schuster, New York, NY. 
Mills, A.J. Weatherbee, T.G. and Durepos, G. (2014), "Reassembling Weber to reveal the pastas-history in management and organization studies", Organization, Vol. 21, No. 2, pp. 225243.

Mills A.J., Suddaby, R., Foster, W.J. and Durepos, G. (2016), "Re-visiting the historic turn 10 years after: Current debates in management and organizational history - an introduction", Management \& Organizational History, Vol. 11, No. 2, pp. 67-76.

Miskell, P. (2018), "Reflections on the integration of history and organization studies", Management \& Organizational History, Vol. 13, No.3, pp. 213-219.

Moses, D. (2005), "Hayden White, traumatic nationalism, and the public role of history", History and Theory, Vol. 44, No. 3, pp. 311-332.

Myrick, K., Mills, J.H. and Mills, A.J. (2013), "History-making and the Academy of Management", Management \& Organizational History, Vol. 8, No. 4, pp. 345-370.

Muldoon, J. (2019), "Stubborn things: Evidence, postmodernism and the draft of history", Journal of Management History, Vol. 25, No. 1, pp. 125-136.

Muldoon, J. (2020), "Conflicting visions: A recap about the debates within management history". In: Bowden, B., Muldoon, J., Gould, A. and McMurray, A. (eds.), The Palgrave Handbook of Management History, Palgrave, London, pp. 1-23, https://link.springer.com/referenceworkentry/10.1007/978-3-319-62348-1 5-2

Neitzsche, F. (1874), On the Use and Abuse of History for Life. http://la.utexas.edu/users/hcleaver/330T/350kPEENietzscheAbuseTableAll.pdf

Nietzsche, F. (1883/1970), Thus spoke Zarathustra, Penguin Books, London, UK.

Paul, H. (2011), Hayden White: The Historical Imagination, Polity, Cambridge, UK.

Rowlinson, M. (2004), "Historical perspectives om organization studies: Factual, Narrative, and Archeo-Genealogical". In: Hodgson, D.E. and Carter, C. (eds.), Management Knowledge and the New Employee. Ashgate Publishing Co., Burlington, VT, pp. 8-20.

Rowlinson, M. (2013), "Management \& organizational history: the continuing historic turn", Management \& Organizational History, Vol. 8, No. 4, pp. 327-328.

Rowlinson, M. and Carter, C. (2002), "Foucault and history in organization studies", Organization, Vol. 9, No. 4, pp. 527-547. 
Rowlinson, M. and Hassard, J. (2013), "Historical neo-institutionalism or neo-institutional history", Management \& Organizational History, Vol. 8, No. 2, pp. 111-126.

Salk, J. (1979), "Introduction”. In: Latour, B. and Woolgar, S., Laboratory Life: The Construction of Scientific Facts, Second edition, Princeton University Press, Princeton, NJ, pp. 11-14.

Sarte, J-P. (1966 / 1971), "An interview: Replies to structuralism”, Telos, Vol. 9, No. 1, pp. 110116.

Schelling, F.W.J. (1809/2006), Philosophical Investigations into the Essence of Human Freedom. State University of New York Press, Albany, NY.

Schopenhauer, A. (1859/1969), The World as Will and Representation, third edition, Dover Publications, Dover, NY.

Shaffner, E.C., Mills, A.J. and Mills, J.H (2019), "Intersectional history: Exploring intersectionality over time", Journal of Management History, Vol. 25, No. 4, pp. 444-463.

Smith, A. and Russell, J (2016), "Toward polyphonic constitutive historicism: A new research agenda for management historians", Management \& Organizational History, Vol. 11, No. 2, pp. 236-251.

Sokal, A. (1996 / 2000) “Lingua Franca roundtable, May 1997". In: Lingua Franca editors (eds.), Sokal Hoax: The Sham that Shook the Academy, University of Nebraska Press, Lincoln, NE, pp. 253-265.

Sokal, A. (1997 / 2000) "A please for reason, evidence and logic". In: Lingua Franca editors (eds.), Sokal Hoax: The Sham that Shook the Academy, University of Nebraska Press, Lincoln, NE, pp. 249-252.

Sokal, A. and Bricmont, J. (1997 / 1998), Fashionable Nonsense: Postmodern Intellectuals' Abuse of Science, Picador, New York, NY.

Suddaby, R. and Greenwood, R. (2005), "Rhetoric strategies for resistance", Administrative Science Quarterly, Vol. 50, No. 1, pp. 35-67.

Thompson, E.P. (1978) The Poverty of Theory, https://www.marxists.org/archive/thompsonep/1978/pot/intro.htm

Van Lent, W. and Durepos, G. (2019), "Guest editorial: Nurturing the historic turn: 'history as theory' versus 'history as method'", Journal of Management History, Vol. 25, No. 4, pp. 429-443. 
Von Ranke, L. (1821 / 1973), “On the historian's task”. In: Von Ranke, L. (trans. W.A. Iggers and K. von Moltke), The Theory and Practice of History, Bobbs-Merrill, New York, NY, pp. 523.

Waldman, M. (1981), "The 'otherwise noteworthy year 711': A reply to Hayden White", Critical Inquiry, Vol. 7, No. 4, pp. 784-792.

Weatherbee, T.C., McLaren, P.G. and Mills, A.J. (2015), "Introduction - The historic turn in management and organizational studies: A companion reading". In: McLaren, P.G., Mills, A.J. and Weatherbee, T.C. (eds.), The Routledge Companion of Management and Organizational History, Routledge, London and New York, pp. 3-10.

White, H. (1963), "The abiding relevance of Croce's idea of history”, Journal of Modern History, Vol. 35, No. 2, pp. 109-124.

White, H. (1966), “The burden of history”, History and Theory, Vol. 5, No. 2, pp. 111-134.

White, H. V. (1968), "Romanticism, historicism, and realism: Toward a period concept for early $19^{\text {th }}$ century intellectual history". In: White, H.V. (ed.), The Uses of History: Essays in Intellectual and Social History presented to William $H$ Bossenbrook, Wayne State University Press, Detroit MI, pp. 15-58.

White, H. (1973a), Metahistory: The Historical Imagination in Nineteenth-century Europe, John Hopkins University Press, Baltimore and London.

White, H. (1973b), "Foucault decoded: Notes from underground", History and Theory, Vol. 12, No. 1, pp. 23-54.

White, H. (2005), "The public relevance of historical studies: A reply to Dirk Moses", History and Theory, Vol. 44, No. 3, pp. 333-338.

White, H. (2014), The Practical Past, Northwestern University Press, Evanston, IL.

Wilson, J.M. (2014), “Henry Ford vs assembly line balancing”, International Journal of Production Research, Vol. 52, No. 3, pp. 757-765.

Wilson, J.M. (2015), "Ford's development and use of the assembly line, 1908-1927". In: Bowden, B. and Lamond, D. (eds.), Management History: Its Global Past and Present, Information Age Publishing, Charlotte, NC, pp. 71-92. 
